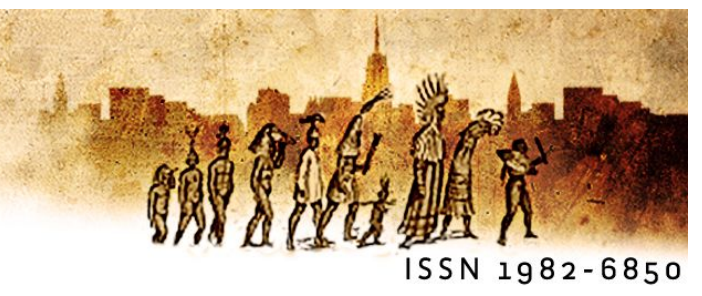

\title{
História e ficção no romance grego e o caso de Siracusa em Quéreas e Calírroe, de Cáriton de Afrodísias
}

\author{
Lucia Sano (Unifesp)
}

\begin{abstract}
Resumo: Este artigo trata da natureza essencialmente mimética do romance grego, investigando como exemplo os usos da historiografia no gênero e, em particular, o caso de Siracusa em Quéreas e Calírrroe, de Cáriton de Afrodísias (século I d.C.), possivelmente o primeiro exemplar do gênero e referência primordial para os demais romancistas gregos. Cáriton parte de um dos episódios mais conhecidos da historiografia antiga (a derrota dos atenienses em Siracusa em 415 a.C.), explorando o conhecimento lacunar de seus leitores a respeito dos personagens nela envolvidos para escrever uma obra fictícia e de temática amorosa que busca, contudo, de alguma forma inscrever-se dentro das limitações impostas pela tradição historiográfica.
\end{abstract}

Palavras-chave: Romance grego, historiografia, Cáriton de Afrodísias, Quéreas e Calírroe.

Abstract: This paper is focused on the essentially mimetic nature of the Greek novel, investigating the uses of historiography in the genre and in particular the case of the representation of Syracuse in Chariton of Aphrodisias' Chaereas and Callirhoe (first century CE), arguably the first exemplar of the genre and a primordial reference for the other Greek novelists. Chariton begins from one of the best known episodes of the Greek historiography (the defeat of the Athenians in Syracuse in 415 BCE), exploring the lacunar knowledge of his readers to write an erotic work of fiction that tries, nevertheless, to comply with the constraints imposed by the historiographic tradition.

Key-Words: Greek novel, historiography, Chariton of Aphrodisias, Chaereas and Callirhoe.

As narrativas ${ }^{1}$ de autoria de Cáriton de Afrodísias (Quéreas e Calírroe), Xenofonte de Éfeso (As Efesíacas), Longo (Dáfnis e Cloé), Aquiles Tácio (Leucipe e Clitofonte) e Heliodoro (As Etiópicas) fazem parte de um grupo de textos que apresentam um tal número de características

\footnotetext{
${ }^{1}$ Agradeço a leitura e sugestões de Adriane Duarte, Christian Werner, Breno Sebastiani, Jacyntho Brandão e Cláudio Aquati.
} 
comuns que nos permite percebê-los como um gênero, ${ }^{2}$ mas um gênero para o qual nenhum autor antigo parece ter se preocupado em estabelecer preceitos ou mesmo uma denominação.

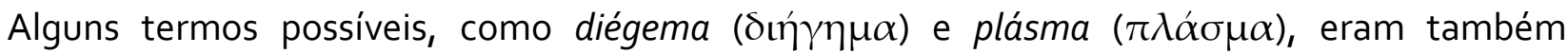
utilizados em referência a outros gêneros literários na Antiguidade e não são, portanto, escolhas ideais. Na falta de um termo grego para nomeá-los, utilizamos prontamente um termo latino atestado pela primeira vez na França do século XII, salvos que estamos de outra querela que os falantes de língua inglesa têm de enfrentar, que envolve a opção entre os termos romance e novel. Ambos se referem a narrativas de ficção em prosa, com a diferença de que o primeiro pressupõe uma nuança de idealização e sentimentalismo ausente no segundo. Pode parecer uma complicação menor, mas Reardon ${ }^{3}$ acredita que o uso do termo romance teve implicações sérias na recepção do gênero antigo, resultando em desinteresse crítico.

Ficamos, então, com "romance", ainda que se possa discutir quanto o romance "antigo" difere do "moderno" e se podemos, de fato, considerá-los um único gênero. Alguns teóricos do romance deliberadamente apresentam definições que possam abranger de Cáriton de Afrodísias a Guimarães Rosa, ao passo que outros se detêm em técnicas narrativas e em questões temáticas e históricas que distinguem o fenômeno da ficção narrativa em prosa surgido no período imperial romano daquele que ascende com a modernidade. ${ }^{4} \mathrm{O}$ fato é que um "leitor comum" percebe hoje os textos produzidos pelos autores gregos mencionados no início deste artigo como romances, mas porque atualmente o termo identifica um gênero em prosa que pode tratar de temas inúmeros e utilizar as mais diversas técnicas narrativas. Essa concepção contemporânea, contudo, não afasta o romance moderno do antigo, uma vez que também este é uma forma aberta, capaz de tomar aspectos diversos ao incorporar e transformar em romanescos variados elementos dos demais gêneros literários - algo

\footnotetext{
${ }^{2}$ Sobre o estabelecimento do corpus canônico do romance grego de amor, cf. P. Ipiranga Jr. (2014).

3 "'Romance' é sobre princesas e dragões; ele não é realista, não é sério. Ainda que pareça trivial agora, acredito que essa nomenclatura é uma questão substancial e ajuda a explicar a negligência anterior dessa forma literária entre os pesquisadores de língua inglesa" (REARDON, 2006, p.229). Fusillo (2006, p. 36) observa sobre o romance grego que "enquanto o gênero continha elementos que eram característicos do romance, ele estava mais próximo do novel em conceito, ao menos pela ausência de elementos fantásticos e a presença da dimensão cotidiana".

${ }^{4}$ A restrição do uso do termo "novel" resulta em parte da definição de lan Watt em seu The Rise of the Novel (1957), que quer que ela seja (idem, p.8) "suficientemente estreita para excluir tipos de narrativas anteriores e ainda ampla o suficiente para ser aplicada a qualquer coisa normalmente colocada na categoria de 'novel'". Essa definição serve ao seu propósito de relacionar a emergência do gênero à Revolução Industrial e à expansão do número de leitores.
} 
exemplarmente traduzido na expressão narrador gramatofágico, empregada por Brandão (2005).5 De fato, vários dos outros elementos considerados característicos do romance moderno foram observados também no antigo, como, por exemplo, a secularização, o isolamento do herói, o foco no privado e no sentimental e o sincretismo cultural (cf. REARDON, 1991 e FUSILLO, 2006).

A investigação moderna sobre a prosa de ficção antiga tem seu marco com a publicação em 1876 de Der Griechische Roman und Seine Vorläufer, de Erwin Rohde. Leitor de sua época e ignorante dos dados que as descobertas papirológicas trariam à tona algum tempo depois, Rohde faz uma análise que, embora seja uma demonstração da sua erudição ímpar, é bastante equivocada em suas conclusões. Suas ideias, contudo, foram muito influentes e apontaram o caminho pelo qual a crítica seguiria por várias décadas. O desdém de Rohde por seu objeto de estudo não era pequeno e a questão que movia seu interesse era desvendar como o romance havia "surgido" a partir da combinação de outros gêneros literários pré-existentes. A tese do estudioso alemão era a de que o romance seria produto da prosa praticada em exercícios retóricos, que teria permitido o "cruzamento" entre a poesia erótica alexandrina e os relatos de viagem helenísticos. Combinados elementos dessas duas práticas literárias pelos alunos de retórica do período imperial teríamos tido como resultado o romance de amor e aventura. Os hoje datados pressupostos de Rohde fizeram-no estabelecer uma cronologia incorreta para os romances que conhecemos; o texto de Cáriton de Afrodísias, por exemplo, atualmente considerado nosso exemplar mais antigo, foi por ele reconhecido como o último dos romances, uma vez que a simplicidade de sua narrativa assinalaria a tal "decadência" do gênero.

A contestação definitiva da tese de Rohde foi feita apenas em 1967, por Ben Perry, em The Ancient Romances: a Literary-Historical Account of their Origins, cujo título anuncia uma grande mudança de perspectiva, ainda que alguns dos postulados do crítico alemão já tivessem sido anteriormente questionados. ${ }^{6}$ Embora Perry exagere na sua ojeriza pelo termo "desenvolvimento" (development), que pode designar meramente uma sucessão cronológica

\footnotetext{
5 "A característica mais básica do romance grego (como, em geral, de todo romance) é a capacidade de dialogar com outros gêneros ou, dizendo com mais precisão: uma propriedade que eu não teria receio de chamar de gramatofágica, envolvendo a assimilação e a transformação desses mesmos gêneros" (2005, p.131).

6 Sobre a contribuição dada por Perry aos estudos do romance antigo, cf. Reardon (2006).
} 
nas práticas literárias da Antiguidade, ele aponta o dedo para o que considera uma grande falha do estudo de Rohde, que desconsidera a situação histórica que teria motivado a criação desse novo gênero poético. Igualmente por ele criticados foram os autores que defenderam a então forte hipótese de que o romance teria se originado da historiografia helenística, em um processo de degeneração, Zersetzung, o que Perry chamou com sua verve típica de "uma doença da historiografia". Como bem observa o crítico, não há como um gênero literário dar origem a outro sem que ele tenha que negar a sua própria razão de ser, "passando por um grau zero". Independentemente das revisões pelas quais as ideias de Perry passaram, ${ }^{7}$ ele acrescentou ao debate crítico a ideia fundamental de que para o surgimento do romance foi preciso um motivo, mais do que elementos formais disponíveis para sua composição. Não se tratava de reconhecer partes distintas que teriam se combinado formando um novo gênero, mas de perceber como causa desse fenômeno novos impulsos da sociedade grega, cujos anseios não estavam mais representados nas práticas literárias então existentes.

Mesmo que Perry tenha demonstrado como era equivocada a análise "biológica" da origem do romance, isso não quer dizer que se estivesse negando que os romancistas gregos se apropriaram de diversos elementos de outras práticas literárias em seu processo de composição. Trata-se apenas de uma mudança de perspectiva: passa-se a entender que a relação com as formas canônicas não é de uma simples dissolução, mas faz parte de um processo criativo de um grupo de indivíduos em diálogo com práticas literárias tradicionais e que faz uso de diversos de seus elementos com propósitos variados. Essa capacidade de apropriação e de transformação de outros gêneros é característica essencial do romance; basta para entendê-lo ler o primoroso texto de Longo, Dáfnis e Cloé, no qual a poesia bucólica de Teócrito e a comédia nova combinam-se como principais fontes de emulação; ou o livro IX de As Etiópicas de Heliodoro, cuja matriz historiográfica é evidente. Isso fica claro também no confuso processo de classificação dos fragmentos de romances. Quando se publicou pela primeira vez um fragmento de Sesoncôsis, por exemplo, ele foi identificado como parte de uma

7 Muitas das hipóteses de Perry já não são hoje bem aceitas pela crítica. Bowie (2002) lançou as ideias que resultaram em uma nova percepção das origens do romance, advogando pela datação de Cáriton e Xenofonte de Éfeso no período imperial e demonstrando que as evidências apontam para o nascimento do gênero nesse momento na Ásia menor. Essas hipóteses foram exploradas com um grande arsenal de dados epigráficos e arqueológicos por Tilg (2010). Ambos os estudiosos também defendem que não há motivo para tentar relacionar o surgimento do romance com o contexto histórico-social, visão da qual discordamos.

Eutomia, Recife, 15 (1): 69-91, Jul. 2015 
narrativa historiográfica e só foi reclassificado quando um trecho maior foi descoberto. Um trecho de Metíoco e Partenope foi de início considerado "filosófico" porque trata do poder do amor nos moldes do Banquete, de Platão (STEPHENS; WINKLER, 1993, p.9).

Em alguns casos, quando há alusões claras ou citações, os autores parecem chamar atenção para um modelo com o qual eles desejam se associar, mas nem sempre a relação mimética é evidente. Dessa forma, para o tema amoroso frequentemente são enumerados intertextos vários: a relação de Penélope e Odisseu, a poesia lírica e elegíaca dos períodos arcaico e helenístico, a comédia nova, a história de Panteia e Abradatas na Ciropédia, de Xenofonte, o casal Medeia e Jasão de Apolônio de Rodes, os tristes relatos amorosos de Partênio, além de outras possíveis fontes. Não temos como saber como o primeiro romancista elaborou a ideia de um casal que se apaixona perdidamente à primeira vista e que só poderá ter seu final feliz quando as aventuras que os separam tiverem fim e seu casamento puder ser celebrado ou retomado e não podemos precisar que modelos esse autor tinha em mente; assim, se Homero é citado com frequência, por outro lado, em nenhum dos romances se menciona explicitamente Panteia e Abradatas. ${ }^{8}$

A questão da apropriação da tradição literária não é, no entanto, destinada à aporia como parece ser a das origens do romance e deixa registros claros nos textos, ainda que não possamos reconhece-los todos. Os autores das narrativas que possuímos empenham-se para tornar evidente o processo imitativo do qual se valem ao longo da composição e a ocorrência de termos metapoéticos é frequente. É fato que as alusões e citações fazem parte de um trabalho individual de cada um dos romancistas e possuem um grau mais ou menos refinado dependendo do autor, mas no geral se observa o que Fusillo (1991, p.20) descreve como "uma tendência de reescrever em tom trivial a tradição literária, algo que coexiste com a tendência oposta de enobrecer a narrativa".9

\footnotetext{
8 Embora A. Capra (2009) faça uma ótima análise dos nomes do casal protagonista de As Efesíacas, de Xenofonte de Éfeso, apontando a influência da história de Abradatas e Panteia na sua escolha.

9 Assim, Fusillo (2005) reconhece, por exemplo, nos romancistas gregos e latinos formas diferentes de apropriação da tradição épica. Na vertente latina cômica do romance, representada por Petrônio e Apuleio, seria marcado um distanciamento entre o romance e a poesia épica, gênero elevado. No caso dos gregos, ao contrário, o crítico defende que uma das principais funções da alusão à poesia épica é a de elevar um gênero que, sendo uma prática literária recente, careceria de verniz; esse procedimento seria observável principalmente em Heliodoro e Cáriton.
} 
Como narrativa de extensão razoável, episódica e de tipo misto, o romance se relaciona principalmente com a épica e com historiografia. Os críticos concordam sobre a importância da Odisseia para a configuração do gênero, a ponto de Fusillo (1991, p. 24ss) afirmar que, deixada de lado a distinção entre verso e prosa, seria possível afirmar que o poema de Homero é o "primeiro romance grego". A identificação da Odisseia com o romance advém não apenas do seu tema, que conjuga aventuras e união no casamento, mas também da forma como é elaborada e estruturada a narrativa. Além disso, o fato de que se trata de ficção é tão evidente que pode passar por desimportante, mas aqui vale lembrar que, quando Aristóteles afirma na Poética que não é em metrificar ou não que diferem historiador e poeta (1451b), embora se preveja a possibilidade da ficção em prosa, ela ainda demoraria alguns séculos para surgir.

O segundo gênero do qual os romancistas são mais claramente devedores é a historiografia. Uma evidência de como os romancistas se viam como herdeiros de uma determinada vertente da historiografia é o fato de que, além de Xenofonte de Éfeso (séc. I d.C.), outros dois romancistas conhecidos apenas pela Suda têm o mesmo nome, Xenofonte Cíprio e Xenofonte de Antioquia, possivelmente três pseudônimos inspirados em Xenofonte de Atenas (V-IV a.C.). Essa provável relação é estabelecida principalmente em razão da Ciropédia, obra que guarda várias semelhanças com os primeiros romances, a ponto de ser às vezes também considerada um. ${ }^{10}$ No entanto, se também na Ciropédia, como nos romances de amor, elementos históricos parecem constituir pouco além de pano de fundo contra o qual o narrador inscreve a história da vida de um personagem idealizado, Ciro, o Grande, o texto de Xenofonte distancia-se da prática romanesca do período imperial pela centralidade dos propósitos didático e paradigmático da obra. Nesse sentido, se a trágica narrativa erótica de Panteia e Abradatas aproxima a Ciropédia do romance, sua posição marginal no interior da obra de Xenofonte os distancia. ${ }^{11}$

No período da Antiguidade em que escrevem os romancistas, a relação verdade-ficção é ainda uma via de mão-dupla: não só a ficção se apropria de elementos historiográficos, mas a

\footnotetext{
10 Mais recentemente, cf. Zimmerman (2009).

11 Como bem nota Tatum (1994), o aspecto moralizante da obra de Xenofonte faz com que esse episódio erótico ensine uma lição sobre os perigos de sucumbir ao amor e demonstre a exemplaridade do caráter de Ciro, que logo de início evita ser tentado pela beleza de Panteia, recusando-se a encontrá-la.
} 
historiografia pode se valer, em maior ou menor grau, com intuitos diversos, de elementos fictícios e adornos retóricos. ${ }^{12}$ Além disso, mais do que de Heródoto, Tucídides e Políbio, uma vertente da historiografia helenística teria se desenvolvido nos moldes de um autor como Ctésias de Cnido, historiador do final do século $V$ a.C. tachado de mentiroso desde a Antiguidade, ${ }^{13}$ cuja História Persa e um relato de viagem à Índia são resumidos por Fócio (cod. 72). Hägg (1983, p.14) descreve bem o resumo da primeira obra ao afirmar que nela "os fatos históricos lutam uma batalha inglória com o desejo de chocar, comover, excitar e deslumbrar". Essa extensa obra, escrita em vinte e três livros, se inscrevia no limite entre narrativa histórica e narrativa fictícia. Holzberg (2003, p.630) observa que um fragmento da História Persa de Ctésias (P.Oxy.2330) "contém o relato de um caso amoroso e tanto os seus motivos quanto o estilo simples da obra de Ctésias possuem forte semelhança com o tipo de escrita que se encontra no romance grego". Para Holzberg, a abordagem de Ctésias ao seu tema pode indicar que o seu círculo de leitores fosse menos "culto" do que os leitores de, por exemplo, Tucídides, e que esse mesmo público poderia ter vindo a ser o dos primeiros romances gregos. A se julgar pela menção de Ctésias nas Histórias Verdadeiras de Luciano (I.3), porém, creio que não se pode considerar que o autor não fosse lido por um público educado, a despeito das críticas que sofresse.

Temos em Ctésias e Xenofonte dois exemplos de autores que inserem elementos fictícios em narrativas que podemos chamar históricas, antecipando uma combinação de elementos observada nos romances, cujo ponto mais importante, porém, é o uso deliberado de certo "colorido historiográfico" que tem como objetivo construir um efeito de plausibilidade. Essa forte relação com a historiografia seria justificada pelo fato desse "verniz" ter sido, nos primeiros romances, para além da função de enobrecer um gênero recém-criado, um fator importante para garantir uma recepção adequada, uma vez que a chamada a "crença ficcional", em que opera a suspensão dos critérios de verdade para a recepção bem-sucedida do texto era

\footnotetext{
12 Para se ter uma ideia de como os historiadores que se contentavam em narrar apenas fatos verídicos eram artigo raro na Antiguidade, basta ler os exemplos de maus historiadores que escreveram sobre a Guerra dos Partos, elencados por Luciano em Como se Deve Escrever a História, embora seja necessário ponderar o tratamento cômico e, portanto, provavelmente distorcido que lhes é dado em uma obra na qual o autor se empenha em estabelecer os limites dos gêneros poético e historiográfico.

${ }_{13}$ O primeiro crítico talvez tenha sido Aristóteles (cf. Hist.Anim. 606a8), mas ele é criticado com severidade por Estrabão e Fócio (cod.72) e é considerado um paradigma de autor mentiroso por Luciano nas Histórias Verdadeiras (I.2). Sobre o autor, cf. Cizek, (1975), Holzberg (1996) e Romm (1989).
} 
construído a partir de um conhecimento da tradição historiográfica grega compartilhado pelo autor e seus leitores (cf. MORGAN, 1993).

A intenção de criar uma história plausível, que dê ao leitor a sensação de "isso poderia ter acontecido", implica não só que os personagens se movam em um mundo próximo do conhecido pelo leitor (pela experiência ou, melhor ainda, pela leitura, uma vez que os enredos se localizam temporalmente no período clássico da história grega, alguns séculos antes do momento em que foram escritos), mas também que os romancistas empreguem elementos reconhecíveis como próprios do gênero que lida com fatos verídicos. Um caso importante no que diz respeito aos temas tratados nos romances, por exemplo, é a reprodução de uma tensão entre civilização grega e o mundo bárbaro, observável em todos os romancistas com exceção de Longo, ausência justificada por se tratar do único caso em que os protagonistas não se distanciam do local onde vivem. Quanto às técnicas narrativas tomadas da historiografia, um uso importante pode ser observado, por exemplo, quando o narrador de Heliodoro expressa dúvida sobre o que é relatado. Ora, se a dúvida diz respeito a fatos reais, ela bem pode ser uma dúvida real do autor, mas quando essa expressão se refere a fatos inventados pelo próprio romancista, vemos claramente um narrador romanesco adotando uma postura de historiador (cf. MORGAN, 1982 e 2007).

Por outro lado, o romance permitia desvios consideráveis dos textos dos quais seus leitores possivelmente tinham conhecimento. Podemos observar mais claramente esse processo nos poucos fragmentos conhecidos de Nino (séc. I a.C. ou d.C.). O tratamento idealizado do personagem, rei lendário fundador do Império Assírio, levou à hipótese de que a obra fosse uma espécie de Ninopédia, fortemente influenciada pela Ciropédia de Xenofonte. Há que se considerar que nossa principal fonte histórica sobre Nino e sua esposa Semíramis ${ }^{14}$ é um breve sumário de Diodoro Sículo (II.1-20) do que teria escrito a respeito dos dois o historiador Ctésias de Cnido, cuja fama de mentiroso já foi mencionada. Porém, as diferenças entre a Semíramis de Ctésias e a do autor de Nino são muitas e permitem avaliar a liberdade dos romancistas no processo de idealização típica do gênero. No fragmento A, o futuro rei,

${ }_{14} \mathrm{O}$ nome de Semíramis não aparece nos fragmentos, mas em Diodoro Sículo se diz que ela é filha da deusa Derceto e o nome de sua mãe nos fragmentos é Derceia, claramente um derivado. Ainda que o casamento de Nino com Semíramis tenha aparentemente se tornado um tema tradicional da historiografia grega, há uma distância de cerca de 1500 anos entre os períodos em que cada um deles teria vivido.

Eutomia, Recife, 15 (1): 69-91, Jul. 2015 
apaixonado por sua prima, confronta a mãe de sua futura esposa argumentando contra a convenção que estabelece quinze anos como a idade apropriada para uma moça se casar, pois Semíramis teria ainda de esperar dois anos até que os dois pudessem celebrar sua união. A Semíramis do romance é, ao menos na passagem que possuímos, tão acanhada que sequer consegue tocar no assunto casamento com sua tia, a mãe de Nino, por ter vergonha de falar (fr.A-IV.20-37).

Essa Semíramis pouco tem a ver com a da tradição historiográfica que conhecemos. Isso não significa, porém, que ela forneça um retrato "realista" da rainha, figura mítica que adquiriu progressivamente características que a associam à deusa mesopotâmica Ishtar que, por sua vez, é relacionada sobretudo às esferas amorosa e militar. Diodoro Sículo diz, a partir da obra de Ctésias, que Nino se casa com Semíramis, durante uma expedição contra a Báctria, tomando-a do seu marido Onnes, seu aliado (que por isso se mata). Nessa campanha, Semíramis tem oportunidade de demonstrar sua habilidade como estrategista, ajudando o exército a tomar a última cidade que permanecia em resistência, chamando assim a atenção do rei. Após a morte de Nino, Semíramis teria sido responsável por fundar a cidade de Babilônia e por liderar campanhas militares no Egito, na Etiópia e na Índia, sendo derrotada apenas nesse último país. Diodoro (II.13.4) diz ainda que a rainha se entregava à luxúria e, tendo receio de perder o poder, não desejava se casar, mas escolhia alguns soldados e depois matava todos aqueles com quem havia mantido relações. Depois de relatar a versão de Ctésias, Diodoro (II.20.3-5) afirma que outras fontes dizem que Semíramis era, na verdade, uma cortesã, que conseguiu se casar com Nino. Como esposa, ela teria convencido o rei a deixá-la governar em seu lugar durante cinco dias, período no qual conspirou contra o próprio marido e assassinou-o, tomando o poder de forma permanente.

Em Cáriton de Afrodísias, o uso de elementos historiográficos é bastante saliente, menos por estratégias narrativas, como é o caso de Heliodoro, e mais pela ambientação. A obra apresenta aspectos de um romance histórico, ainda que a rigor não possamos chamá-lo dessa forma, uma vez que a acuidade na representação do período clássico não é objetivo do autor. No entanto, o romance, de fato, como apontou Hägg (1987), apresenta alguns traços característicos do subgênero. Cáriton, que escreve provavelmente no século I d.C., narra 
acontecimentos que datariam do século IV a.C., ainda que a construção dessa realidade histórica seja pontuada de anacronismos. Parte de seus personagens é facilmente identificável em registros históricos: o pai da heroína, Calírroe, é Hermócrates de Siracusa, famoso líder que derrotou a expedição ateniense em 415 a.C., fato a que o narrador alude ao longo da história com frequência. O Grande Rei é identificado com Artaxerxes II, que governou a Pérsia entre os anos de 404-358 a.C. ${ }^{15}$

Estivesse Cáriton criando uma nova forma literária, sendo o protos heuretés do gênero, como defendeu recentemente Tilg (2010), ou seguindo um modelo primordial hoje perdido, é visível que o autor criou o seu romance com o intuito de que ele fosse percebido em contraste com os gêneros canônicos. Vemos ao longo da narrativa diversas citações de Homero integradas à própria voz do narrador, em uma demonstração de erudição que o autor parece supor compartilhar com seus leitores. Os efeitos desse jogo de referências permitem refletir acerca do próprio status que o autor deseja dar à sua obra, inserindo o romance na tradição literária grega. Assim, Cáriton evoca também Tucídides e Heródoto nas frases inicial (discutida

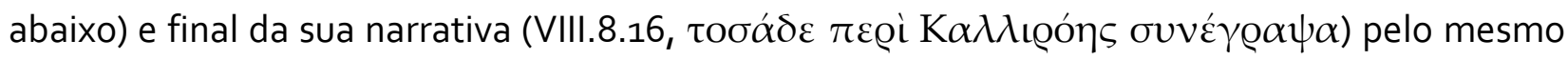
motivo que talvez o tenha levado a escolher como tema do seu romance não qualquer história de amor, mas a que envolve o conhecimento de um importante episódio político da Grécia clássica: pode-se estar trabalhando em um novo gênero, mas se estabelece desde o início a paideia do autor. Cáriton, contudo, vai além ao explorar essa relação, valendo-se das alusões à tradição literária para também enfatizar o que é próprio do romance, em oposição a ela.

O breve prólogo de Quéreas e Calírroe, aliás, parece a princípio preparar o leitor para uma narrativa de caráter historiográfico, mas que ao mesmo tempo declara como seu objeto um páthos erotikón, criando-se assim uma tensão entre um estilo que sugere o tratamento de grandes questões públicas e o tema que se anuncia na sequência, voltado à vida privada dos personagens:

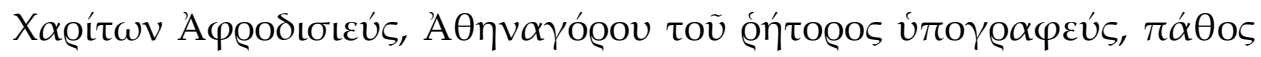

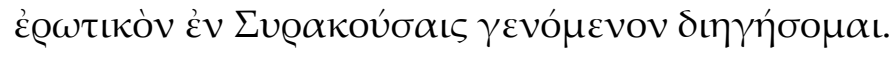

\footnotetext{
${ }_{15}$ Um dos anacronismos de Cáriton: Hermócrates teria morrido no ano de 408 a.C., antes de Artaxerxes II subir ao poder.
}

Eutomia, Recife, 15 (1): 69-91, Jul. 2015 
Eu, Cáriton de Afrodísias, secretário do retor Atenágoras, narrarei uma paixão erótica acontecida em Siracusa.

O uso do nome próprio ${ }^{16}$ na abertura da obra evoca a historiografia clássica e o aposto

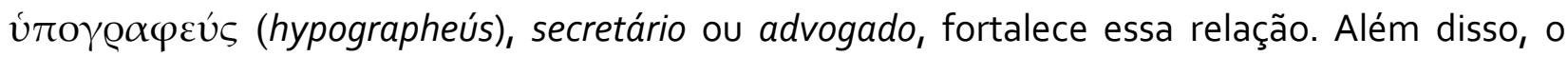

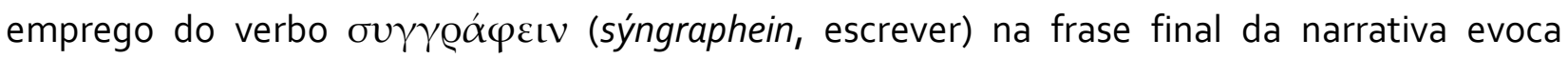
imediatamente seu uso na abertura de A História da Guerra do Peloponeso de Tucídides e, como observa Brandão (2005, p.114), aponta nesse período com mais propriedade à escritura da história: "mais importante é que o narrador se apresente como hypographeús, isto é, escriba, notário, secretário - o que dá à sua narrativa certo ar documental". Não se trata de qualquer escritor, mas o de um tipo que deve manter algum controle sobre sua liberdade autoral, de modo que fique garantido o registro dos fatos. ${ }^{17}$ Além disso, historiadores contemporâneos de Cáriton não utilizavam a fórmula com que ele introduz o romance, o que parece indicar que o autor desejava "comunicar, desde o início, o espírito da própria época em que o enredo se passa" (HÄGG, 1987, p.195). ${ }^{18}$ Por fim, o páthos erotikón evidencia a centralidade do elemento amoroso na narrativa, sobrepujando os demais, que se configuram fortemente, ao longo do romance, como questões da esfera pública e política. ${ }^{19}$ A tensão acentuada entre esses dois

\footnotetext{
${ }^{16}$ Cf. Doulamis (2012) para discussão sobre relação entre autor/narrador em Cáriton.
}

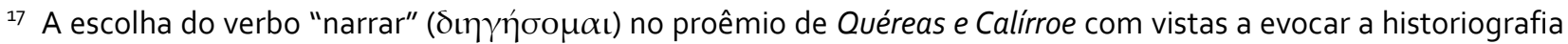
clássica foi recentemente colocada em questão por Tilg (2010, p. 218), que, ao contrário, vê nessa escolha a marca

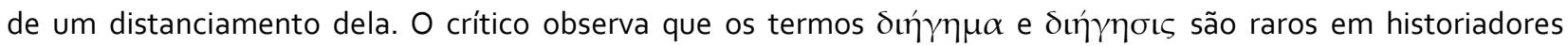
clássicos e, de fato, ausentes em Heródoto, Tucídides e Xenofonte. Obras de historiografia posteriores, em que o uso do verbo se torna mais comum, teriam sido influenciadas por um conceito retórico de narrativa como discutida nos progymnasmata, que classifica a historiografia na categoria de $\delta ı n ́ \gamma \eta \mu \alpha$.

18 Já se levantou também a hipótese de que o prólogo fosse fictício ou o nome do autor, um pseudônimo, por se considerar demasiadamente apropriado que um escritor da cidade de Afrodite, a deusa do amor, cujo nome faz referência às Graças (Cárites), fosse o autor de uma paixão erótica. Se fictício, o Atenágoras mencionado poderia fazer referência ao mesmo indivíduo que Tucídides apresenta como oponente de Hermócrates (VI.35-40), travestindo-se, assim, o romance de relato de testemunha ocular dos acontecimentos em Siracusa, como sugeriu D'Orville (apud TILG, 2010, p.49ss). Ainda que alguns críticos continuem a achar plausível o uso do pseudônimo, descobertas arqueológicas em Afrodísias parecem contextualizar historicamente a criação de Quéreas e Calírroe de modo convincente (cf. TILG, idem, ibid.).

19 Brandão discute a expressão "páthos erotikón" (2005, 1835s): "a especialização do termo registra-se em testemunhos como o de Partênio, ao apresentar seu livro como áthroisin tôn erotikôn pathemáton - 'coleção de paixões amorosas' ou, como se costuma traduzir, coleção de romances de amor".

$$
\text { Eutomia, Recife, } 15 \text { (1): 69-91, Jul. } 2015
$$


polos se encerra, no fim da narrativa, em uma sugestão de coexistência harmoniosa.

Os personagens principais de Cáriton movem-se e têm parte decisiva numa esfera política que envolve não só a cidade de Siracusa, mas também o Império Persa, o que é igualmente reflexo da relação que o autor escolhe manter com a historiografia clássica. Embora, como observa Reardon, "as pressuposições inconscientes que subjazem na história" (1996, p.326) estejam de acordo com aquelas do período do Império Romano, o "colorido histórico" é sentido onde os leitores podem reconhecer a tradição literária grega. Isso tem consequências na criação dos personagens masculinos, que ocupam posições sociais no romance que lhes permitiriam vir a ser igualmente personagens de narrativas historiográficas. Como nota Alvares (1997, p.620), o que acontece com Calírroe na corte persa "deve ser visto em relação aos relatos de história persa como uma série de intrigas da corte e do harém, que remontam a Ctésias e a Duris e que pode ser observada em A Vida de Artaxerxes, de Plutarco".

Cáriton toma como ponto de partida um fato bastante conhecido da história grega, mas, assim como o autor de Nino, também seleciona e reelabora diversos de seus elementos. A leitura de Tucídides não parece indicar que Hermócrates fosse o responsável por liderar as operações militares em Siracusa e o sucesso da cidade talvez dependa mais da atuação do espartano Gilipo. No entanto, Diodoro Sículo (13.96.3) o menciona como responsável por derrotar os atenienses em guerra e, no momento em que Cáriton escreve, tanto Siracusa quanto Hermócrates já haviam recebido tratamento idealizado diversas vezes, não só com relação a sua excelência militar, mas também a uma perfeição moral (BILLAUT, 1989). A ideia de que Hermócrates é o responsável pela vitória de Siracusa é repetida tantas vezes no romance que, para Billaut (idem, p.542), "[ela] tem a pureza de uma abstração. Ela não contradiz a verdade histórica, mas aparece abstrata da história como sucessão de acontecimentos no tempo". ${ }^{20}$ No romance, o general é o principal líder político da cidade; mais do que isso, ele é uma figura que se impõe desde o início da narrativa como aquela que define quem são, afinal, Calírroe e Quéreas: ela é, como o narrador repete inúmeras vezes, a filha de Hermócrates,

\footnotetext{
20 Billaut (1989, p.542) observa, contudo, que "não há dúvida de que aos olhos de Tucídides ele reunia as virtudes necessárias a um chefe valoroso: energia, acuidade intelectual, capacidade de prever os acontecimentos e também coragem de contradizer a opinião do povo". O crítico analisa a representação de Hermócrates não só em Tucídides e Xenofonte, mas em Timeu de Tauromenon, Políbio, Diodoro Sículo e Plutarco, dando, porém, especial atenção ao Hermócrates do diálogo platônico Timeu.
} 
aquele que derrotou os atenienses; Quéreas é o seu genro. Em determinada passagem do romance, irritada ao ouvir o eunuco Artaxates dizer que ela prefere o "escravo de Mitridates" ao próprio rei, Calírroe tenta provar a grandeza e a superioridade de Quéreas ao persa por meio de um raciocínio que se centra na história militar das pátrias de um e de outro (VI.7.9-10):

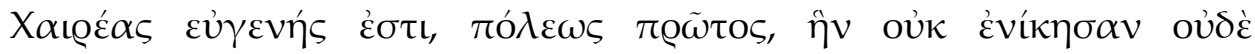

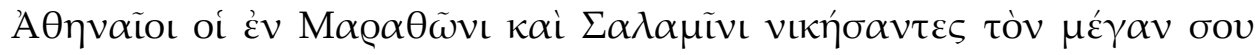
$\beta \alpha \sigma \iota \lambda \dot{\alpha} \alpha$.

Quéreas é nobre, o primeiro de uma cidade que nem os atenienses derrotaram, aqueles que em Maratona e em Salamina venceram o teu Grande Rei.

Nada se diz no romance sobre o governo democrático em Siracusa que acabou por exilar Hermócrates, muito menos sobre o golpe que ele então empreende para tomar a cidade, durante o qual acaba morto. Dionísio I, aliado de Hermócrates que, por fim, torna-se tirano de Siracusa, teria se casado com sua filha. Plutarco (Dionísio, 3.1-2), que não registra seu nome, diz que ela teria se suicidado após ter sido violentada por um grupo de rebeldes. Assim, como observa Tilg (2010, p. 155), "o fim histórico trágico dos dois é substituído por um romântico final feliz".

Pode-se concluir que os romancistas consideraram ser apropriado, quando trabalhavam com material historiográfico, selecionar eventos sobre os quais seus leitores teriam um conhecimento lacunar. ${ }^{21}$ Esse é um dos motivos por que o pirata Téron, a despeito da sugestão dos companheiros, decide não tentar vender Calírroe em Atenas, alegando que não Ihe

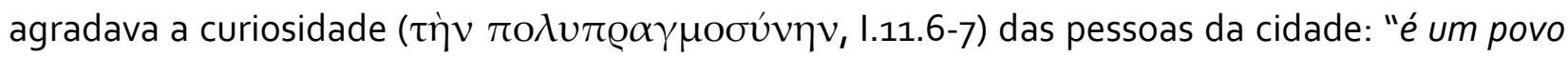
tagarela e amante dos tribunais e, no porto, sicofantas aos milhares vão querer saber quem somos e de onde trazemos as mercadorias [...]. E logo ali está o Areópago e os magistrados, mais severos que tiranos". É natural que se levante a possibilidade de Calírroe ir parar em Atenas, já que a cidade é evocada desde o início do romance pela vitória militar de Hermócrates. A própria Calírroe, quando raptada pelos piratas, expressa seu receio de acabar escrava de um senhor ateniense. Para ela, há ironia no fato de que isso viria a concretizar uma situação que havia sido

\footnotetext{
${ }^{21}$ Além de Quéreas e Calírroe e Nino, também pensamos nos fragmentos de Metíoco e Partenope.
} 
evitada com a vitória de Siracusa em guerra, mas a ideia surge para ser logo depois descartada. Em função da própria forma como a disputa por Calírroe é representada, uma passagem por Atenas traria ao universo do romance outros personagens históricos mais familiares aos leitores, uma vez que ela desperta o desejo de pretendentes que têm posição política de destaque, influenciando em sua atuação. Assim, a reescrita com final feliz de eventos históricos em um novo gênero, com novo sistema de valores e no qual é possível dar a conhecer as motivações pessoais e eróticas dos homens públicos que determinam o destino de um coletivo, só pode se dar em um espaço que favoreça a inserção de elementos fictícios. ${ }^{22}$

Mas como Cáriton conjuga o tema do amor, a característica mais essencial do romance grego, a questões públicas e políticas tomadas da historiografia? Para essa pergunta, é interessante a análise de Alvares (1997), que discute como Cáriton adapta motivos conhecidos da historiografia para criar um contraste com o gênero, pois elementos políticos e sociais teriam sua importância diminuída ao serem representados como meros elementos do poder de Afrodite. E poderíamos ver isso acontecer não apenas quando Dionísio, Mitridates e o próprio rei Artaxerxes se apaixonam por Calírroe, três homens que são da maior importância no universo político persa e que, quando a conhecem, passam a atuar dentro dessa esfera influenciados pelos seus sentimentos. Além disso, a própria estrutura geral dos acontecimentos é organizada em torno do poder de Afrodite, uma vez que ao final do romance se revela que tudo o que aconteceu com Quéreas após a morte aparente de Calírroe foi motivado pelo descontentamento da deusa com ele.

Discordo, porém, da sua interpretação da narrativa. Para Alvares, o período glorioso de Siracusa estaria distante e mítico o suficiente no momento em que Cáriton compõe seu romance para permitir ser reescrito numa "história alternativa", de forma a demonstrar que seguir os valores de Afrodite pode levar a uma trajetória política de sucesso. A nova ordem que

\footnotetext{
${ }^{22}$ A recusa de Téron é também, como sugeriram alguns críticos, uma escolha anunciada de Cáriton de se distanciar de gêneros literários mais antigos. Kaspryzk (2001) observa que uma das funções do pirata, ao levar primeiro a heroína à Ásia e, em seguida, o herói, é possibilitar um elemento que diferencia o romance da comédia nova. De início, a intriga amorosa e o vocabulário teatral no episódio da conspiração dos ex-pretendentes sugerem uma aproximação com o gênero (cf. LOWE, 2000 e MASON, 2002). Smith (2007, p. 66ss.) considera que se trata também de uma recusa da historiografia ática, bem como Tilg (2010, p. 32 ss.) que, além disso, sugere a relação do romance com os contos milésios como motivação para a escolha de Mileto como destino dos personagens. Para a escolha de Mileto como cidade onde boa parte da ação se passa, cf. Trzaskoma (2012).
} 
Quéreas, ao lado de sua esposa, inauguraria seria superior às realizações do passado e "resultado da devoção aos valores eróticos". O crítico argumenta que os principais rivais de Quéreas não demonstram possuí-los, sugerindo que a regra no romance é que se deve ter um único par durante toda a vida e que, por isso, Dionísio agiria de forma inapropriada ao esquecer sua falecida esposa e se casar com Calírroe, não sendo, portanto, digno de um final feliz. Devemos considerar, porém, que o próprio Quéreas (VII.1.6) parece acreditar que o segundo casamento de Calírroe seria compreensível se ele estivesse morto. Além disso, a relação entre amor e sucesso político não é, de fato, apresentada pelo narrador como uma equação simples.

A construção da excelência militar de Quéreas, por sua vez, durante a revolta egípcia narrada no livro VII diz respeito principalmente à capacidade estratégica e de liderança dos gregos, algo ainda mais enfatizado com a escolha democrática de Quéreas como comandante da expedição contra a cidade de Tiro. Ao fazer o herói lutar ao lado dos egípcios e no comando de trezentos homens dórios, há uma tentativa de Cáriton de alinhar Quéreas numa luta política contra um estado opressor, reproduzindo em outro contexto a relação entre Siracusa e Atenas da forma como é descrita no romance. Ainda que, como diversos dos personagens, Quéreas tenha motivações eróticas para se envolver na guerra, ele só assume uma postura ofensiva nesse momento no romance, quando sua atuação não poderia mais ser entendida como a de um agressor, mas, pelo contrário, fortalece uma revolta contra um governo tirânico. Ao final da história, a Sicília representa um lugar para onde escapar da tirania (cf. DOODY, 1996, p.194) e diversos dos subjugados à Pérsia escolhem a cidade como novo lar quando descobrem que a revolta egípcia havia sido contida.

Uma vez que reencontra Calírroe, porém, a rivalidade política é colocada em segundo plano e Quéreas logo se declara arrependido de ter lutado contra o Grande Rei, quando a esposa Ihe informa que ele não havia feito nada contra ela (VIII.1.16):

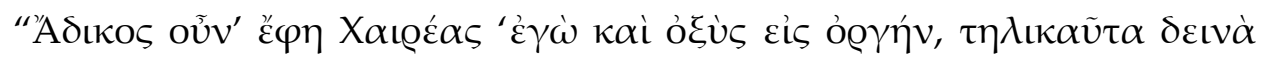

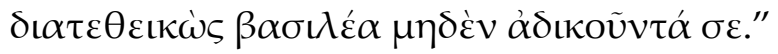

"Então eu fui injusto", disse Quéreas, "e também excessivo em minha raiva, por ter colocado o rei em uma situação tão terrível sem que ele tenha te feito nenhum mal". 
A rapidez com que o personagem assume ter sido injusto com o rei persa é significativa (ainda que Quéreas tenha de ser dissuadido por Calírroe a tornar a rainha persa sua escrava) e vai refletir-se adiante, quando ele afirmar para o povo de Siracusa, reunido no teatro, que conquistou para a cidade a amizade do rei ao devolver as mulheres persas tomadas como cativas (VIII.8.10). Por causa do estranhamento que essa mudança súbita de disposição provoca, buscou-se justificar a atitude de Quéreas. Uma tentativa é a tese de Laplace (1980, p. 615s.), para quem o personagem não é apenas comparável a Alexandre, o Grande, por ter, como ele, tomado a cidade de Tiro, mas por ser magnânimo na relação que estabelece com os persas derrotados, emulando as atitudes do general macedônio. Assim, sua vitória não reforça o ódio, mas leva à substituição do ódio ancestral pela amizade, inaugurando um mundo "à imagem do sonho de Alexandre", construído literariamente com forte influência da Ciropédia de Xenofonte.

Todavia, a relação entre Siracusa e Pérsia já havia sido mencionada anteriormente como amigável, quando Dionísio afirma que o Grande Rei todo ano enviava presentes a Hermócrates para honrá-lo pela vitória contra os atenienses, um inimigo comum (II.6.3). E a própria caracterização do rei persa é positiva; seu desejo por Calírroe é apresentado como algo irresistível e, ainda que ele não seja capaz de controlá-lo, recusa-se a tê-la em seus braços por meio da coação. Além disso, o que causa a indignação de Quéreas no início do livro VII, quando ele acredita que sua esposa havia sido entregue a Dionísio, nunca chegou a acontecer. Se a guerra é o melhor juiz dos pretendentes de Calírroe, como se afirma duas vezes no romance (VII.5.15, na fala do rei em favor de Dionísio e VIII.4.2, na carta de Quéreas para o rei), o narrador parece sugerir que o envolvimento de Quéreas na luta dos egípcios contra a tirania persa ocorre por um engano.

O que isso significa? Diversos críticos têm considerado as complexas relações políticas que se desenham no romance como, de alguma forma, manifestação pensada como resposta ao contexto histórico-social no qual Cáriton teria escrito sua obra, quando os gregos estavam sob domínio romano. ${ }^{23}$ Não se quer descartar a validade dessas hipóteses, mas o próprio

\footnotetext{
${ }^{23}$ Para os críticos que adotam essa perspectiva, Roma está "tanto em nenhuma parte quanto em toda a parte" nos romances gregos, como observou Schwartz (2003, p.392). Um exemplo são os importantes estudos de Swain (1998) e Lalanne (2006), que interpretam o gênero como uma forma literária pela qual as elites gregas representam sua perpetuação por meio de casamentos exclusivamente gregos. Para Alvares (2001-2002), o romance representa um desejo de que os gregos pudessem, dada a sua excelência, de alguma forma negociar sua
} 
desenvolvimento da narrativa justifica determinadas ações de seus protagonistas. Hunter (1994, p. 1061) interpreta, por exemplo, a recusa de Hermócrates de retardar punição ao pirata Téron, que vendera sua filha como escrava, como "manifestação poderosa do que é um dos principais temas da obra - a supremacia da lei sobre a desigualdade e a tirania". Relacionados a esse tema estariam dois outros, a supremacia dos gregos e da cultura grega sobre as bárbaras e a dos homens livres sobre os escravos e os de baixo status social. Esse conjunto de ideias que perpassa o romance contribui para a construção de um discurso que, como já se afirmou, pretende dar à narrativa um colorido histórico. Por outro lado, essa característica do romance faz com que os eventos e personagens localizem com certa acuidade os fatos do enredo e não permitam uma reescrita da história que crie situações descoladas do seu contexto "real". Revoltas egípcias foram diversas apenas no século IV a.C. (cf. SALMON, 1961), o que justifica plenamente aquela de que Quéreas participa, mas a escravização da rainha e das mulheres da aristocracia persa em Siracusa não poderia senão levar a novos conflitos. Parece-me, no entanto, que essa forma de contornar um impasse narrativo é introduzida pelo rápido apaziguamento do ânimo de Quéreas para demonstrar que o herói, inicialmente destemperado, sabe agora também o momento certo de interromper sua raiva, tendo em vista relações políticas mais positivas para sua cidade. ${ }^{24}$

A devolução da rainha persa, Estatira, ao grande rei, que havia sido capturada no butim, permite ao narrador, por outro lado, ressaltar a generosidade de Calírroe e apresentá-la como conselheira indispensável a Quéreas, que parece não conseguir perceber as terríveis consequências que levar a rainha persa à Siracusa poderiam ter. Anteriormente, ela já havia impedido que o marido declarasse aos soldados que o rei egípcio havia sido capturado em

\footnotetext{
liberdade com os romanos. Smith (2007), estudando especificamente Quéreas e Calírroe, analisa as questões de tirania e democracia presentes no romance tendo em vista que elas seriam de especial interesse aos gregos subjugados ao poder romano. Schwartz (op.cit.), por sua vez, acredita que o império persa no romance deve ter chamado atenção dos membros da elite grega para alguns aspectos do poder romano, ou ao menos para uma percepção de si próprios como culturalmente superiores ao povo que o dominava. Concordo, porém, com as considerações de Tilg (2010) de que a relação extremamente cooperativa entre Afrodísias e Roma não parece corroborar tais interpretações. Parece-me interessante, no entanto, a sugestão de Schwartz (op.cit.) de que a representação positiva do tirano persa no romance pode ser justificada por ele ser a "autoridade masculina suprema" no seu reino. Demonizá-lo poderia chegar próximo de atacar as bases ideológicas do próprio império romano.

${ }^{24}$ Defendi, em minha tese de doutorado (2013), seguindo Balot (1998), que é possível ver um amadurecimento em Quéreas ao longo da narrativa, representado pelo controle das emoções, sobretudo da raiva.
} 
combate, o que provocaria uma revolta dos prisioneiros do qual resultaria, provavelmente, na captura de todos os gregos. Mais do que demonstrar a sua inteligência e sensibilidade, o narrador procura enfatizar como os seus conselhos podem ser úteis a um homem que assume uma posição de liderança. Ao longo da narrativa se insinua o efeito negativo que o Amor pode ter sobre os homens e sua atuação política e é importante ressaltar no fim do romance que ele pode também ser positivo, em especial se a mulher ao lado do general for a filha de Hermócrates, de quem tenha herdado algo do tino político. Isso não significa que Quéreas é um tolo que depende de Calírroe para tomar as decisões acertadas porque, a partir da sua sugestão, ele rapidamente decide escrever ao Grande Rei exigindo a anistia para os revoltosos egípcios em troca da liberdade da rainha (VIII.4.3). ${ }^{25}$

Quando o casal finalmente retorna à pátria, os siracusanos a princípio suspeitam que os atenienses possam estar preparando novo ataque, mas os gregos fingem ser mercadores egípcios para atracar na cidade. Logo, porém, revelam-se à multidão Calírroe, em leito de ouro, e Quéreas, com as insígnias de general (VIII.6.7). Seu retorno é então comparado ao dia da vitória sobre os atenienses (VIII.6.10):

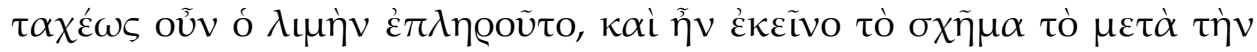

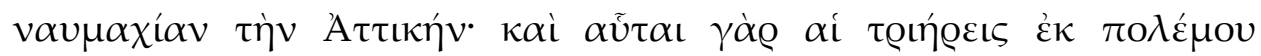

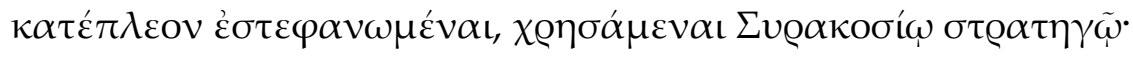

Rapidamente o porto se encheu e tinha o mesmo aspecto do dia após a batalha naval contra Atenas, pois também essas trirremes voltavam da guerra vitoriosas, sob o comando de um general siracusano.

A glória de Quéreas é a glória da cidade. A multidão pede para que todos se dirijam à assembleia, para que possam ouvir o relato do que se passou. O povo está reunido no teatro, mas Calírroe se retira para descansar e a tarefa de contar tudo o que aconteceu desde a partida de Siracusa fica para Quéreas, a "estrela em ascensão" no cenário político da cidade. Ele

\footnotetext{
${ }^{25}$ Além disso, a reação de Calírroe, que fica chocada com a sugestão de levar a rainha persa como sua serva, demonstrando-lhe gratidão pela hospitalidade e proteção a ela reservada durante a guerra, altera o foco das relações entre gregos e persas, que deixa de ser uma rivalidade política e passa a ser a de uma amizade pessoal entre a rainha e Calírroe. "Também tu vais recuperar o teu marido" (VIII.3.8), diz a siracusana à rainha persa. No último livro, afirma o narrador, o leitor poderá se alegrar com "amores justos e casamentos legítimos" (VIII.1.4), no plural.
} 
começa, no entanto, pelo fim, hesitando em contar as tristezas pelas quais passou inicialmente. É aí que Hermócrates intervém de forma decisiva, encorajando-o a relatar tudo o que se passara (VIII.7.4): "Não te envergonhes de nada, meu filho, se contares algo mais doloroso ou indigno de nós, pois havendo final feliz, ele ofusca todos os fatos passados."

Essa passagem diz respeito ao próprio enredo do romance de amor. Prestes a narrar as aventuras que ele e a esposa viveram para o povo siracusano, Quéreas torna-se um duplo do narrador. Não importam o rapto por piratas e o segundo casamento de Calírroe, nem a redução de Quéreas e de Policarmo a escravos de Mitridates ou as angústias vividas na Babilônia. ${ }^{26} \mathrm{O}$ romance caminha para um final feliz ( $\tau \dot{\lambda} \lambda o \varsigma \lambda \alpha \mu \pi$ @óv, télos lamprón) capaz de redimir todos os males e as faltas dos heróis. Essa estrutura convencional do romance de amor, observável nos cinco exemplares supérstites que possuímos, leva a uma seleção de fatos no enredo, principalmente no caso de um bem localizado no tempo e no espaço como o do romance de Cáriton, que busca ofuscar a continuidade histórica dos eventos. Ora, já se demonstrou como o autor opta por uma caracterização quase mítica de Hermócrates, que ignora seu posterior exílio de Siracusa e sua tentativa de golpe.

No relato feito por Quéreas, ele não deixará de mencionar (VIII.7.12) o filho que ele e Calírroe geraram e que ela deixou em Mileto com o seu segundo marido, Dionísio, que acredita ser ele o pai da criança, um cidadão siracusano que ficou aos cuidados de um homem persa de prestígio. Na carta que Calírroe havia escrito a Dionísio e que Estatira, a rainha persa, fica encarregada de entregar, ela havia pedido (VIII.4.5-6) que, quando adulto, Dionísio o enviasse a Siracusa para conhecer o avô Hermócrates. Há muito se sugeriu uma identificação dessa criança com o futuro tirano Dionísio I de Siracusa que, segundo Plutarco, teria se casado com a filha do general siracusano. ${ }^{27}$ Embora, para considerar tal identificação, seja necessário dar conta das diversas mudanças que Cáriton introduziria nos eventos históricos (a esposa se torna mãe), tendo a concordar com Connors (2002, p. 17) que "em contraste com a visão típica de Dionísio como um tirano ruim (Diod.Sic.14.2; Cic.Tusc.5.57-63), o fato de Cáriton imaginar de modo

\footnotetext{
${ }^{26}$ Embora o relato de Quéreas não coincida exatamente com o que aconteceu. Cf. Temmerman (2009) para uma análise completa dos discursos de Quéreas na parte final da narrativa, que demonstram que um aspecto importante do amadurecimento do personagem é a sua capacidade de manipulação dos fatos e o controle sobre outras pessoas. Isso inclui distorcer fatos que possam ser constrangedores para ele ou para Calírroe.
}

27 Naber (1901) apud Smith (2007, p.246). Contra, Tilg (2010, p.46).

Eutomia, Recife, 15 (1): 69-91, Jul. 2015 
otimista a chegada do filho de Calírroe a Siracusa apresenta um retrato geral mais venturoso do futuro do tirano". Finais felizes talvez não sejam exclusivamente possíveis na ficção, mas no romance grego são obrigatórios. No romance "quase histórico" de Cáriton de Afrodísias, a felicidade do casal precisa também ser a garantia da bem-aventurança da cidade.

\section{Referência Bibliográfica}

ALVARES, J. "Chariton's Erotic History", American Journal of Philology 118, 1997, p. 613-29. "Some Political and Ideological Dimensions of Chariton's Chaireas and Callirhoe", Classical Journal 97, 2001-2002, p. 113-44.

BALOT, R. "'Foucault, Chariton, and the masculine self", Helios 25.2, 1998, p. 139-62.

BASZLES, M. "De l'histoire au roman: la Perse de Chariton", In: BASLEZ, M., HOFFMAN, P.,TRÉDÉ, M. (eds), Le Monde du Roman Grec, Paris: École Normale Supérieure, 1992, p.199-212.

BILLAUT, A. "De l'histoire au roman: Hermocrate de Syracuse", Revue de Études Grecques, n.102, 1989, p.540-548

. La Création Romanesque dans la Littérature Grecque à l'Époque Impériale, Paris:

Presses Universitaires de France, 1991.

BOWIE, E. "The chronology of the earlier Greek novels since B.E. Perry: revisions and precisions", Ancient Narrative 2, 2002, p.47-63.

BRANDAO, J. A Invenção do Romance, Brasília: UNB, 2005.

BRANHAM, R. "A Truer Story of the Novel?", In: BRANHAM, R. (ed.), Bakhtin and the Classics, Evanston, Northwerstern University, 2002, p.161-186.

CAPRA, A. "'The (Un)happy Romance of Curleo and Liliet'. Xenophon of Ephesus, the Cyropaedia and the birth of the 'anti-tragic' novel", Ancient Narrative 7, 2009, p.29-50.

CONNORS, C. "Chariton's Syracuse and its Histories of Empire", In: PASCHALIS, M., FRANGOULIDIS, S. (eds.), Space in the Ancient Novel, Groningen: Barkhuis, 2002, p. 12-26.

DE TEMMERMAN, K. (2009). "Chaereas revisited. Rhetorical control in Chariton's ideal novel Callirhoe", Classical Quaterly n. 59, v.1, p.247-262. 
DOODY, M. The True Story of the Novel, New Brunswick: Rutgers University Press, 1996.

DOULAMIS, K. "All's Well that Ends Well: Storytelling, Predictive Signs, and the Voice of the Author in Chariton's Callirhoe", Mnemosyne, Volume 65, Number 1, 2012, p. 18-39.

EDWARDS, D. "Defining the Web of Power in Asia Minor: The Novelist Chariton and His City Aphrodisias", Journal of the American Academy of Religion, vol. 62, 1994, p. 699-718.

FUSILLO, M. Naissance du Roman, Paris: Du Seuil, 1991.

. "Metamorphosi Romanesche dell'Epica". In: MONTANARI, F., RENGAKOS, A. (eds.), La Poésie Épique Grecque: Métamorphoses d"un Genre Littéraire, Vandoeuvres/Genève, 2005, p. 271-307.

. "Epic, Novel", In: MORETTI, F. The Novel: Forms and Themes, 2006, Princeton: Princeton University Press, p.32-63.

HÄGG, T. The Novel in Antiquity, Oxford, Basil Blackwell, 1983.

. "'Calirrhoe' and 'Parthenope': The beginning of the historical novel", Classical Antiquity, vol.26, n.2, 1987, p.184-204.

HOLZBERG, N."Ctesias". In: SCHMELING, G. (ed.), The Novel in the Ancient World, Leiden: Brill, 1996, p.629-632.

HUNTER, R. "History and historicity in the romance of Chariton", ANRW 2.34.2, 1994, p. 10551086.

IPIRANGA Jr., P. "O romance antigo: teorização e crítica", Eutomia v.1, n.14, 2014, p. 45-65.

KAIMIO, M. "How to Enjoy a Greek Novel: Chariton Guiding His Audience", Arctos 30, 1996, p. 49-73.

KASPRZYK, D. "Théron, pirate, conteur et narrateur dans le roman de Chariton", In: POUDERON, B., HUNZIGER, C., KASPRZYK, D. (eds.), Les personnages du roman grec: Actes du colloque de Tours, 2001, p.149-164.

LAPLACE, M. "Les légendes troyennes dans le roman de Chariton Chairéas et Callirhoe'", Revue des Études Grecques, vol. 93, 1980, p. 83-125.

LOWE, N. The Classical Plot and the Invention of Western Narrative, Cambridge: Cambridge University Press, 2000.

MASON, H. J. "Chaireas in Chariton and New Comedy", Classical Bulletin, vol. 78, 2002, p. 21-7. 
MORGAN, J. "History, romance and realism in the Aithiopika of Heliodoros", Classical Antiquity $1,1982,221-65$.

. "Make-Believe and Make Believe: the fictionality of the greek novels", In: GILL, C., WISEMAN, T. (eds.), Lies and Fiction in the Ancient World, Austin, University of Texas Press, 1993, p. 175-229.

"Fiction and History: Historiography and the Novel". In: MARINCOLA, J. (ed.) The Blackwell Companion to Greek and Roman Historiography, vol.2, Malden: Blackwell Publishing, 2007, p.553-563.

PERRY, B. The ancient romances: a literary-historical account of their origins, Berkeley/Los Angeles: University of California Press, 1967.

REARDON, B. The form of Greek Romances, Princeton, Princeton University Press, 1991.

."The Ancient Novel at the Time of Perry", In: BYRNE, S., CUEVA, E., ALVARES, J. (eds.). Authors, Authority, and Interpreters in the Ancient Novel, Groningen: Barkhuis, Groningen University Library, 2006, p. 227-238.

ROHDE, E. Der grieschisch Roman und seine Vorlaufer, Charleston: Bibliolife, 2009 (original de 1876).

ROMM, J. The Edges of the Earth in Ancient Thought: Geography, Exploration, and Fiction, Princeton: Princeton University Press, 1994.

SALMON, P. "Chariton d'Aphrodisias et la révolte e'gyptienne de 360 avant J.-C.", Chronique d'Egypte 36, 1961, p. 365-76.

SANO, L. Sendo Homem: A Guerra no Romance Grego, tese de doutoramento apresentada ao Programa de Pós-Graduação em Letras Clássicas da Universidade de São Paulo, 2013.

SCHWARTZ, S. "Rome in the Greek Novel? Images and Ideas of Empire in Chariton's Persia", Arethusa, vol. 36, n. 3, 2003, p. 375-394.

SMITH, S. Greek Identity and the Athenian Past in Chariton. The Romance of Empire, Ancient Narrative Supplementum 9, Groningen: Barkhuis, Groningen University Library, 2007.

STEPHENS, S., WINKLER, J. (eds.). Ancient Greek Novels: The Fragments, Princeton: Princeton University Press, 1993.

TATUM, J. Xenophon's Imperial Fiction, Princeton: Princeton University Press, 1989.

TILG, S. Chariton of Aphrodisias and the Invention of the Greek Love Novel, New York: Oxford Eutomia, Recife, 15 (1): 69-91, Jul. 2015 
University Press, 2010.

TRZASKOMA, S. "Why Miletus? Chariton's Choice of Setting and Xenophon's Anabasis", Mnemosyne 65.2, 2012, p. 300-307.

WATT, I. The Rise of the Novel, Berkeley/Los Angeles, University of California, 1957.

ZIMMERMANN, B. "The historical novel in the Greek world: Xenophon's Cyropaedia". In: KARLA, G., Fiction on the fringe: novelistic writing in the post-classical age, Leiden/Boston: Brill, 2009, p.95-103.

' Professora Adjunta de Língua e Literatura Gregas da Universidade Federal de São Paulo; no momento, me dedico ao estudo da obra de Xenofonte de Atenas e da sua recepção com verba de Auxílio à Pesquisa da Fapesp. Email: lucia.sano@unifesp.br.

Recebido em 13/04/2015 Aceito em 05/06/2015 